\title{
The Anti-Oxidant Effect of Extracts from the Vaccinium oldhami
}

Jung-Woo Chae, Hye-Jin Kong', Mi-Ji Lee', Jung-Yeon Park', Ji-Hyang Kim', Young-Hun Kim³, Chang-Eon Lee ${ }^{1}$ * and Kyung-Hwan Kim

Gyeanggi-do Forest Environment Research Institute, Osan 447-290, Korea

${ }^{1}$ Department of Cosmeceutical Science, Daegu Haany University, Gyeongsan 712-749, Korea

${ }^{2}$ Skin science R\&D Center, Cosmelab Co., Ltd Gyeongsan 712-210, Korea

${ }^{3}$ Skin science R\&D Center, Mediway Korea, Co., Ltd Deague 702-884, Korea

Received June 7, 2010 /Accepted August 14, 2010

\begin{abstract}
Natural compounds have been studied to substitute synthetic antioxidants. In this study, the anti-oxidant activity of $70 \%$ acetone extracts from the Vaccinium oldhami fruit was investigated for utilization as ingredients for the cosmetic and bio-industries. Anti-oxidant activity was determined by determining total polyphenolic content, electron donating ability, nitric oxide (NO) radical scavenging activity, $\mathrm{ABTS}^{+}$cation radical scavenging activity and hydrogen peroxide scavenging activity. The polyphenolic content of $70 \%$ acetone extracts of the Vaccinium oldhami fruit was $55.972 \mathrm{mg}$ TAE/g. In electron donating activity, 70\% acetone extracts of the Vaccinium oldhami fruit showed an effect of $93.9 \%$, which was similar to BHA effect at a concentration of $500 \mu \mathrm{g} / \mathrm{ml}$. In the NO radical scavenging ability, $70 \%$ acetone extracts of the Vaccinium oldhami fruit showed $60 \%$ at $500 \mu \mathrm{g} / \mathrm{ml}$. ABTS ${ }^{+}$cation radical scavenging activity of the Vaccinium oldhami fruit at a concentration of $1000 \mu \mathrm{g} / \mathrm{ml} \mathrm{was} 75.7 \%$. Also, hydrogen peroxide scavenging activity of $70 \%$ acetone extracts showed $80.8 \%$ at $100 \mu \mathrm{g} / \mathrm{ml}$, whichwas higher than BHA. In the natural compound market, the most important factors are the ability to obtain high effects of a material in low concentrations and a long-lasting supply. The Vaccinium oldhami fruit can be harvested every year - this fulfills one of the requirements. From these results, we can confirm that the Vaccinium oldhami fruit has anti-oxidant abilities and has potential as a natural anti-oxidant agent to be utilized in the cosmeceutical and bio-industries.
\end{abstract}

Key words : Vaccinium oldhami, anti-oxidantive activity, phenolic compound, cosmeceutical

\section{서 론}

현대인은 산소에 의한 산화적 스트레스에 항상 노출이 되어있으며, 이러한 산화적 스트레스는 정상적인 경우 생체 내에 존재하는 항산화계에 의해 제거되지만 산업화 이후 계 속적으로 증가한 각종 환경오염물질, 흡연, 알콜 및 방사선 등은 인체에 산화적 스트레스를 가중시키고 있다. 산화적 스트레스가 제거되지 못하면 생체막의 손상, 고분자 단백질 및 $\mathrm{DNA}$ 의 변형과 기능 상실 등으로 인한 다양한 퇴행성 질환이 유발될 수 있으므로 이로 인해 유발되는 건강문제를 해결할 수 있는 물질로서 항산화제에 대한 관심이 집중되고 있다[11]. 또한, 항산화제는 합성항산화제와 천연항산화제로 구분되며 합성 항산화제인 butylated hydroxyanisole (BHA), butylated hydroxytoluene (BHT), Benzoic acid, p-oxybenzoic ester는 오랫동안 이용되어 왔으나 다량 섭취 시 유해[7]하다는 논문기록 등에 기인하여 합성 항산화제에 대한 소비자의 거부반응으로 그의 수요가 급격히 감소되고

*Corresponding author

Tel : +82-53-819-1594, Fax : +82-31-374-2492

E-mail : forest1004@korea.kr
있는 추세이며, 이를 대체하기 위해 천연물에서 유래된 항산 화 물질에 대한 연구가 활발히 진행되고 있다.

한의학에서는 국내 자생수종이 한약의 재료로 사용 되어 왔으며, 그 가운데 열매는 널리 이용되고 쉽게 접할 수 있는 재료이다. 또한 국민 생활소득의 향상으로 국민들의 기능성 화장품과 기능성 식품의 수요는 증가하고 있고, 기능성 제 품들의 효능 증대를 위하여 천연물들을 사용하여 화장품, 식품, 의약품 산업에 응용되고 있다. 본 연구의 재료인 정금 나무 또한 현재 널리 이용되지 않고 있으나 주 자생지인 전 라북도, 충청남도 및 경기남부에서는 결실기인 10 월 초에 결실량이 풍부하며, 조류에 의한 피해가 거의 발생하지 않 고 주민들이 열매를 채취하여 술이나 음료의 재료로 사용되 고 있다.

정금나무(Vaccinium oldhami)는 진달래과에 속하며, 한국 의 남부, 충남, 충북, 황해도 등지의 산 중턱, 산등성이에 나는 낙엽관목으로 수고는 $2-3 \mathrm{~m}$ 정도이며, 가지의 굵기 또한 지름 $2 \mathrm{~cm}$ 미만이다. 현재까지의 정금나무에 대한 인 체 유효성분 분석은 잎[17]과 가지[20]를 원재료로 하는 연 구는 진행되어 왔으나, 정금나무의 생장특징과 향후 활용 
및 산업화적인 측면에서 검토해 보았을 때 잎 또는 가지를 원재료로 할 경우 영속적인 대량생산과 재료목의 보전이 불가능한 단점이 있다. 반면 열매의 경우, 결실량이 풍부하 고 과육이 자주색을 띄고 있어 향후 제품생산 단계에서 별 도의 화학색소 첨가가 필요치 않을 것으로 사료되며 생육 특징 또한 기존 교목층 아래에서 생육 또는 재배가 가능하 므로, 대단위 면적에서 연중 일정한 수량을 영속적으로 생 산할 수 있는 장점이 있다. 그리고 정금나무 열매를 시료로 한 성분 분석이나 항산화 활성을 알아보기 위한 연구는 지 금까지 사례가 없으므로, 반드시 필요한 연구라고 사료된 다. 이에 본 연구에서는 향후 정금나무 열매의 식품, 화장 품 및 바이오산업 등으로 응용을 위하여 항산화활성을 검증 하였다.

\section{재료 및 방법}

\section{시료 제조}

본 연구에 사용된 정금나무의 열매는 2009년 10월 12 일에 충청남도 태안군 안면읍 일원에서 채취하였다. 시료에 아세 톤과 물을 7:3(volume/volume)의 비율로 넣은 다음 3일 동 안 추출한 후 여과하여 회전 농축기로 감압 농축하여 동결 건조 후 사용하였다.

\section{총 폴리페놀 함량 측청}

총 폴리페놀 함량은 phosphomolybdic acid가 페놀성 물 질과 반응하여 청색으로 발색되는 것을 이용한 Folin-Denis 법[22]을 통해 측정하였다. 즉, 농도별 시료용액 $1,500 \mu 1$ 에 $1 \mathrm{~N}$-Folin-Ciocalteu phenol reagent 시약을 $500 \mu \mathrm{l}$ 가하고 3 분간 반응 후 $10 \%$ 의 포화 $\mathrm{Na}_{2} \mathrm{CO}_{3}$ 용액 $500 \mu \mathrm{l}$ 를 가하였다. 이 혼합액을 1 시간 반응 후 $640 \mathrm{~nm}$ 에서 흡광도를 측정하 였으며, tannic acid를 이용하여 표준곡선으로 함량을 구하 였다.

\section{전자공여능 측정 (Elctron donating ability)}

전자공여능은 Blois 방법[1]을 변형한 1.1-diphenyl-2- picrylhydrazyl (DPPH) free radical 소거법으로 측정하였다. $\mathrm{DPPH}$ 는 자신이 가지고 있는 홀수의 전자 때문에 $517 \mathrm{~nm}$ 에서 강한 흡수 스펙드럼을 보이나 페놀성 화합물과 같이 수소 전자를 제공해 주는 전자공여체와 반응하게 되면 전자 를 제공하는 hydrogen radical을 받아 phenoxy radical을 생성하게 되며 흡수 band도 사라지게 되고 안정한 분자가 된다[2,14]. 즉 $70 \%$ ethanol을 용매로 한 $10,50,100,500$, $1,000 \mu \mathrm{g} / \mathrm{ml}$ 의 농도별 시료액 $100 \mu \mathrm{l}$ 와 $99.9 \%$ ethanol에 용 해 한 $0.2 \mathrm{mM}$ 의 DPPH $50 \mu 1$ 를 넣고 교반한 후 암소에 30
분 반응 후 $517 \mathrm{~nm}$ 에서 흡광도를 측정하였다. 대조군에 대 한 흡광도 감소치를 DPPH 라디칼 소거활성으로 하여 항산 화 활성도를 나타내었다. 이때 상대 활성의 비교를 위하여 양성 대조군으로 $\mathrm{BHA}$ 를 사용하였다.

\section{Nitic oxide radical 소거능 측정}

Nitric oxide (NO) radical 소거 실험은 Marcocci 등의 방 법[15]을 변형하여 다음과 같이 측정하였다. $20 \mathrm{mM}$ phosphate buffer $\mathrm{pH}$ 7.4에 용해시킨 $10 \mathrm{mM}$ sodium nitroferricyanide (III) dihydrate $50 \mu \mathrm{l}$ 과 농도별 시료액 $50 \mu \mathrm{l}$ 를 넣고 $25^{\circ} \mathrm{C}$ 에서 150 분간 반응시켰다. 이 반응액에 griess reagent $100 \mu 1$ 를 넣고 15 분 후 $542 \mathrm{~nm}$ 에서 흡광도를 측정하 여 nitrite 소거활성을 확인하였다.

\section{ABTS cation radical 소거능 측정}

$\mathrm{ABTS}^{+}$radical을 이용한 항산화력 측정은 $\mathrm{ABTS}^{+}$Cation Decolorization Assay방법[19]에 의하여 측정하였다. ABTS (2,2'-azinobis-(3-ethylbenzothiazoline-6-sulphonic acid) 7.4 $\mathrm{mM}$ 과 potassium persulphate $2.6 \mathrm{mM}$ 을 12 시간 이상 암소 에 방치하여 청록색의 $\mathrm{ABTS}^{{ }^{+}}$radical을 형성 시키며 이 용 액은 냉장 보관하였다. radical stock solution은 $734 \mathrm{~nm}$ 에서 흡광도 값이 1.5 가 되도록 몰 흡광계수 $\left(\varepsilon=1.6 \times 10^{4} \mathrm{~mol}^{-1} \mathrm{~cm}^{-1}\right)$ 를 이용하여 methanol로 희석하였다. 이 stock solution 100 $\mu 1$ 에 시료추출 용액 $100 \mu 1$ 을 가한 후 상온에서 1 분 방치하 여 $734 \mathrm{~nm}$ 에서 반응액의 흡광도 변화를 측정하였다.

\section{Hydrogen peroxides 소거능 측정}

Hydrogen peroxide 저해활성은 Jayaprakasha등의 방법 [9]에 의해 측정하였다. 농도 별 시료용액 1,000 $\mu 1$ 와 phosphate-buffer saline (PBS at $\mathrm{pH}$ 7.4)에 녹인 $40 \mathrm{mM}$ hydrogen peroxide solution $2,000 \mu \mathrm{l}$ 를 $37^{\circ} \mathrm{C}$ 에서 10 분간 반응시 킨 후 반응액 중에 저해된 hydrogen peroxide의 양을 230 $\mathrm{nm}$ 에서 흡광도를 측정하였다. 합성 항산화 물질인 $\mathrm{BHA}$ 와 활성을 비교해 보았다.

\section{Tyrosinase 저해활성 측정}

Tyrosinase 저해활성 측정은 Yagi 등의 방법[23]에 따라 측정하였다. 농도별 시료액 $100 \mu 1$ 와 $500 \mu \mathrm{l}$ 의0.175M sodium phosphate buffer ( $\mathrm{pH}$ 6.8)와 $10 \mathrm{mM}$ L-DOPA 녹인 기질액 $200 \mu \mathrm{l}$ 에 $200 \mu \mathrm{l}$ 의 mushroom tyrosinase $(110 \mathrm{U} / \mathrm{ml})$ 을 첨가 후 $25^{\circ} \mathrm{C}$ 에서 2 분간 반응시킨 후 생성된 $\mathrm{DOPA}$ chrome을 $475 \mathrm{~nm}$ 에서 측정하였다. Tyrosinase 저해활성은 시료용액의 첨가구와 무첨가구의 흡광도 감소율로 나타내 었다. 


\section{통계처리}

실험 결과는 3 회 반복 측정 후 평균 $\mathrm{SD}$ 로 나타내었다. 통계분석은 SAS program (SAS Institue, Cary, NC, USA)을 이용하여 분산분석한 후 Duncan의 다중검정을 실시하였으 며, 상관관계를 분석하였다.

\section{결과 및 고찰}

\section{총 폴리페놀 함량}

페놀성 화합물은 식물계에 널리 분포되어 하나 또는 두 개 이상의 수산기로 치환된 방향족환을 가지고 있다[4] 이들 은 phenolic hydroxyl $(\mathrm{OH})$ 기를 가지고 있는데, 이것은 분 자 내 phenolic hydroxyl기가 효소 단백질과 같은 거대 분 자들과 결합하는 성질이 있기 때문에 항산화 작용과 관련한 생체 free radical 들을 안정된 화합물로 형성하도록 하여 산 화 억제 작용을 한다[13]

총 폴리페놀 함량을 tannic acid를 기준 물질로 하여 정금 나무 열매 추출물에 포함되어있는 페놀 함량을 측정한 결과 $55.972 \mathrm{mg} \mathrm{TAE} / \mathrm{g}$ (TAE: Tannic Acid Equivalents)으로 함 유되어 있었다(Table 1). 국내산 식품의 총 폴리페놀 함량 분석을 보고한 결과를 보면[12] 밤 속껍질(Chestnut's inner skin)과 감잎(Persimmon leaf)이 가장 높은 수치를 나타내었 고, $\mathrm{mg} / \mathrm{g}$ 으로 환산하였을 때 둘 다 $57.6 \mathrm{mg} / \mathrm{g}$ 으로 정금나 무 열매추출물과 유사한 함량을 나타내었다.

\section{전자공여능}

안정한 free radical을 함유하는 DPPH분자는 항산화제의 radical 소거능을 평가하기 위해 일반적으로 많이 이용된다 [1]. 생체내의 유해 활성 산소, 유리기 등은 생체막의 구성 성분인 불포화 지방산을 공격하여 과산화물을 축적시키는 데, 이로 인해 생체 기능의 저하 또는 노화를 유발시킨다 $[3,10]$. 이러한 원인물질의 생성을 억제하기 위하여 연쇄반 응차단 항산화제로 산패의 기본 물질인 lipid radical과 반 응하여 안정한 물질로 전환시키거나 연쇄반응 개시 속도를 연장시킨다.

Fig. 1 은 정금나무 열매 추출물의 $10,50,100,500,1,000$ $\mathrm{\mu g} / \mathrm{ml}$ 농도의 DPPH radical의 소거 결과로써, 농도 의존적 으로 DPPH radical 소거능이 증가를 확인 할 수 있었고, $500 \mu \mathrm{g} / \mathrm{ml}$ 에서 $98 \%$ 이상의 소거 활성을 나타내었다. 이는

Table 1. The contents of total polyphenol of Vaccinium oldhami fruit extracts

\begin{tabular}{cc}
\hline Sample & Polyphenol contents $(\mathrm{mg} \mathrm{TAE} / \mathrm{g})$ \\
\hline $\mathrm{Va}^{*}$ & 55.972 \\
\hline
\end{tabular}

$500 \mu \mathrm{g} / \mathrm{ml}$ 농도부터 합성항산화제의 지표물질인 BHA의 $\mathrm{DPPH}$ radical 소거 활성보다 높은 수치를 나타내어 정금나 무의 높은 항산화 효과를 확인할 수 있었다.

\section{$\mathrm{ABTS}^{++}$radical 소거능}

$\mathrm{DPPH}$ radical의 소거활성과 같이 일반적으로 많이 이용 되는 ABTS radical cation 소거 능은 2,2-Azino-bis (3-ethylbenzothiazoline-6-sulfonic acid) diammonnium salt (ABTS)와 potassium persulfate와의 반응으로 $\mathrm{ABTS}^{+}$radi$\mathrm{cal}$ 이 생성되면 특유의 색인 청록색을 띄게 되는데, 시료를 첨가함에 따라 연한녹색으로 decolorization 되는 것을 측정 하는 방법이며, hydrogendonating antioxidant와 chain breaking antioxidant 모두를 측정할 수 있다.

Fig. 2는 정금나무 열매의 ABTS ${ }^{+}$radical cation 소거활성 결과이다. 이는 농도 의존적으로 소거능이 증가함을 보였고 $500 \mu \mathrm{g} / \mathrm{ml}$ 에서 $66.7 \%$ 로 $50 \%$ 가 넘는 활성을 띠었지만, 대조 군인 $\mathrm{BHA}$ 보다는 낮은 소거활성을 확인하였다.

\section{Nitric oxide radical 소거능}

$\mathrm{NO}$ 는 혈액응고 및 혈압조절 기능, 암세포에 대한 면역기 능 등이 있지만, 과량이 존재하면 인체에 유해한 영향을 미 치게 되어 세포손상뿐만 아니라 염증 반응을 비롯한 뇌막 염, 알츠하이머병과 파킨슨병 같은 퇴행성 질환에 중요한 요인으로 작용한다[5]. 또한 superoxide 음이온 $\left(\mathrm{O}_{2}\right)^{-}$과 쉽게 반응하여 매우 반응성이 높고 독성이 강한 산화제인 peroxynitrite $(\mathrm{ONOO})$ 를 생성한다[18].

Fig. 3은 nitric oxide $(\mathrm{NO})$ radical 소거능을 측정한 결

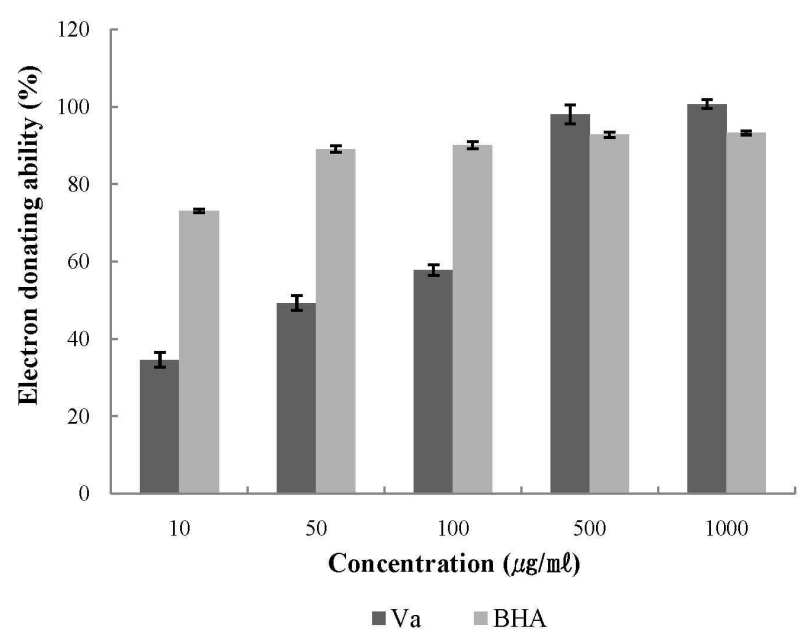

Fig. 1. Electron donating ability of Vaccinium oldhami fruit extract. Va: Vaccinium oldhami, BHA: Butylated hydroxyanisole. 


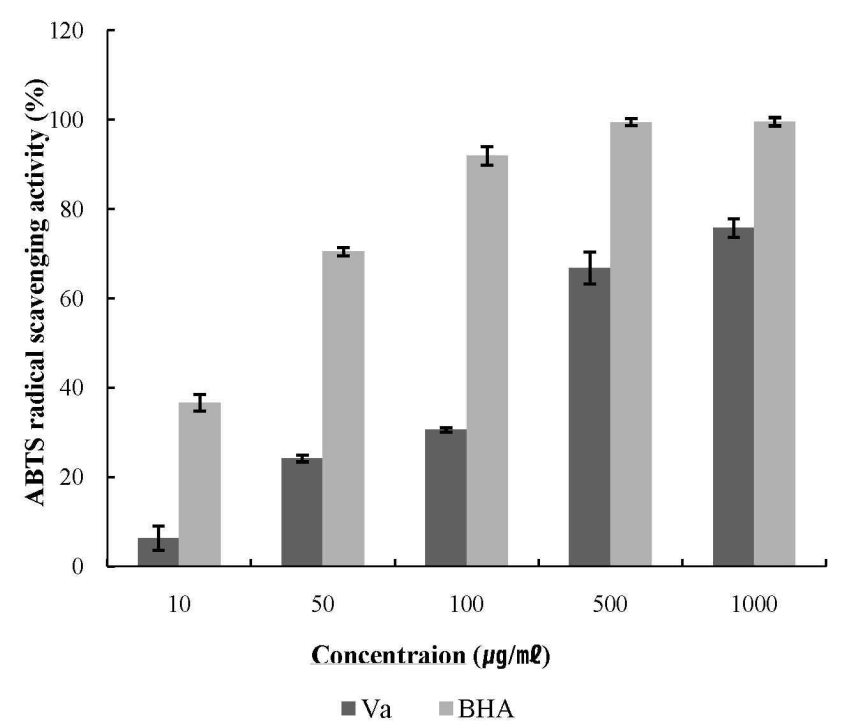

Fig. 2. ABTS radical scavenging activity of Vaccinium oldhami fruit extract. Va: Vaccinium oldhami, BHA: Butylated hydroxyanisole.

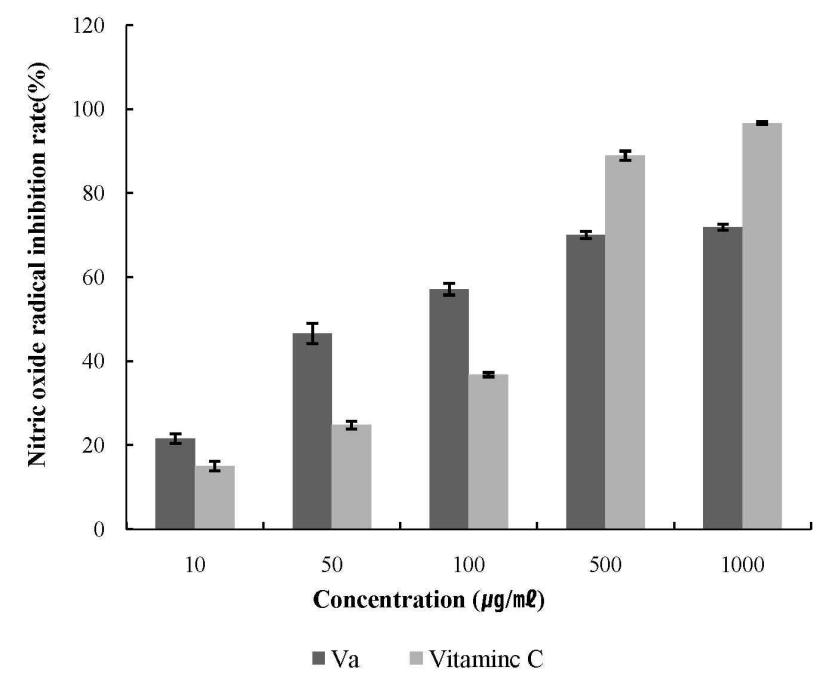

Fig. 3. Nitric oxide scavenging activity of Vaccinium oldhami fruit extract. Va: Vaccinium oldhami, Vitamin C: LAscorbic acid.

과를 나타낸 것으로 $500 \mu \mathrm{g} / \mathrm{ml}$ 이상의 농도에서는 양성 대조군인 ascorbic acid 보다 낮은 활성을 나타내었다. 그 러나 $100 \mu \mathrm{g} / \mathrm{ml}$ 에서 $57 \%$ 로 소거활성을 나타내며, 10 100 $\mu \mathrm{g} / \mathrm{ml}$ 의 낮은 농도에서 ascorbic acid 보다 높은 활성이 나타났다.

\section{Hydrogen peroxides 소거능}

Hydrogen peroxide는 산소의 환원대사물질로서 미토콘

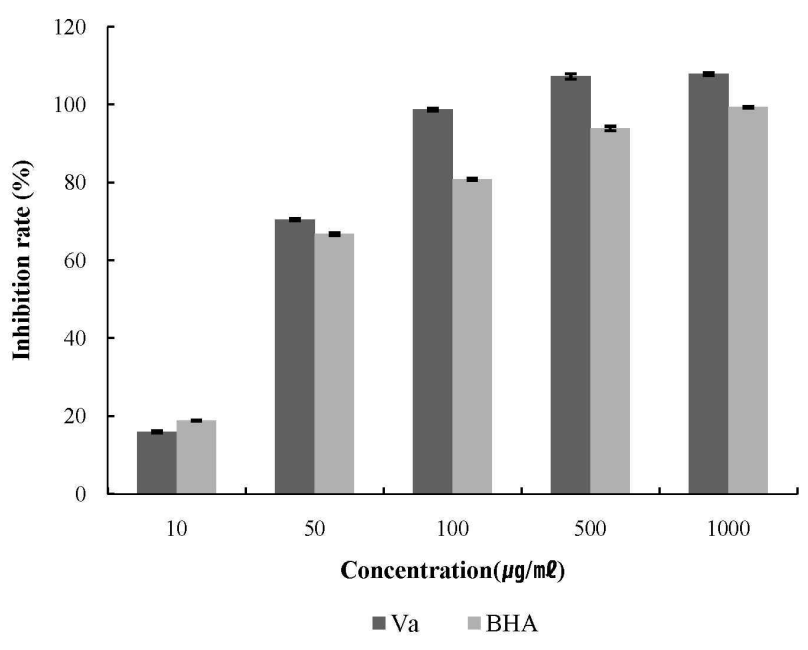

Fig. 4. Hydrogen peroxide scavenging activity of Vaccinium oldhami fruit extract. Va: Vaccinium oldhami, BHA: Butylated hydroxyanisole.



Fig. 5. Inhibition rate of extracts from of Vaccinium oldhami fruit extract on mushroom tyrosianse.Va: Vaccinium oldhami, Vitamin C: L-ascorbic acid.

드리아나 peroxisome 등의 정상세포로부터 형성 되거나 다 양한 외부 요소에 의해 형성되는데, DNA 및 단백질 손상을 유발하거나 생체막 구성 성분인 불포화 지방산을 공격하여 과산화 지질을 생성함으로써 생체기능저하 또는 노화 및 성 인병을 유발하는 것으로 알려져 있다[6,16].

Fig. 4는 정금나무 열매 추출물의 hydrogen peroxide의 소거활성 결과로서 농도 의존적으로 증가 추이를 나타내었 으며, $50 \mathrm{\mu g} / \mathrm{ml}$ 에서 $70 \%, 100 \mathrm{\mu g} / \mathrm{ml}$ 에서 $80.8 \%$ 의 활성을 나타내어 낮은 농도에서도 높은 radical 소거능을 나타내 
며, 대조군인 $\mathrm{BHA}$ 보다 활성이 높게 나타남으로 인하여 정 금나무의 높은 hydrogen peroxides 소거능을 확인 할 수 있었다.

\section{Tyrosinase 저해능}

Tyrosine 활성 억제제는 피부 내에서의 melanin polymer 합성을 효과적으로 저해할 수 있어 피부 미백제의 개 발에 있어서 tyrosinase 활성억제 실험은 유용한 평가법으 로 인정되고 있다. 따라서 tyrosinase는 melanin 생합성 과 정에서 중요한 역할을 하므로 tyrosinase 억제제를 피부의 melanin 색소생성을 조절할 수 있는 물질로 사용할 수 있 다 $[8,21]$.

Fig. 5는 정금나무 열매 추출물의 Tyrosinase 저해능을 나 타내었다. 정금나무 열매의 추출물의 Tyrosinase 저해능은 $5,000 \mu \mathrm{g} / \mathrm{ml}$ 에서 $68 \%$ 의 효과를 나타내었으며 농도 의존적 으로 증가하는 경향을 확인하였다.

\section{References}

1. Blois, M. S. 1958. Antioxidant determination by the use of a stable free radical. Nature 26, 1199-1204.

2. Brand-Wiliams, W., M. E. Cuvelier, and C. Berset. 1995. Use of a free radical method to evaluate antioxidant activity. Technology 28, 25-30.

3. Chance, B., H. Sies, and A. Boveris. 1979. Hydroperoxide metabolism in mammalian organs. Physiol.Res. 59, 527-605.

4. Choi, S. Y., H. S. Cho, and N. J. Sung. 2006. The antioxidative and nitrite scavenging ability of solvent extracts from wild grape (Vitis Coignetiea) skin. J. Korean Soc. Food Sci. Nutr. 35, 961-966.

5. Chung, H. T., H. O. Pae, B. M. Choi, T. R. Billiar, and Y. M. Kim. 2001. Nitric oxide as a bioregulator of apoptosis. Biochem Biophys. Res. Commun. 282, 1075-1079.

6. Finkel, T. and N. J. Holbrook. 2000. Oxidants, oxidative stress and the biology of ageing. Nature 408, 239-247.

7. Hathway, D. E. 1966. Academic press, New York. 15, 1-6.

8. Imokawa, G., and Y. Mishima. 1981. Biochemical characterization of tyrosinase inhibitors using tyrosinase binding affinity chromatography. Br. J. Dermatol. 104, 513-539.

9. Jayaprakasha, G. K., R. L. Jaganmohan, and K. K. Sakariah. 2004. Antioxidant activities of flavidin in different in vitro moder systems. Bioorganic \& Medicinal Chem12, 5141-5146.
10. Jayat, C. and M. H. Ratinaun. 1993. Cell cycle analysis by flow cytometry: principles and applications. Biol. Cell 78, 15-25.

11. Kim, S. I., H. S. Kim, S. Y. Ju, and Y. S. Han. 2009. A study of Antioxidative and Hypoglycemic Activities of Omija (Schizandra, chinensis Baillon) Extract under Variable Extract conditions. J. Korean Food and Nutr. Soc. 22, 41-47.

12. Lee, J. H. and S. R. Lee, 1994. Analysis of phenolic substances content on Korea plant foods. Korean J. Food Sci. Technol. 26, 310-316.

13. Lee, S. H., J. S. Ro, K. S. Lee, Y. J. Ahn, S. J. Kang, B. Y. Hwang, W. Y. Park, and B. T. Ahn. 1996. The phenolic components of Sapium japonicum Yakhak Hoeji 40, 183-192.

14. Lee, S. Y., E. J. Hwang, G. H. Kim, Y. B. Choi, C. Y. Lim, and S. M. Kim. 2005. Antifungal and antioxidant activities of extracts from leaves and flowers of Camellia japonica L. Korea J. Food Sci. and Technol. 13, 93-100.

15. Marcocci, L., J. J. Maguire, M. T. Droylefaix, and L. Packer. 1994. The nitric oxide-scavenging properties of Ginkgo biloba extract EGb 761. Biochem Biophys. Res. Commun. 201, 748-755.

16. Martindale, J. L. and N. J. Holbrook. 2002. Cellular response to oxidative stress: signaling for suicide and survival. J. Cell Physiol. 192, 1-15.

17. Oh, S. J. and S. C. Koh. 2009. Screening of Antioxidative Activity and a-Amylase Inhibitory Activity in Angiosperm Plants Native to Jeju Island. Korean J. Plant Res. 71, Seoul.

18. Radi R., J. S. Beckman, K. M. Bush, and B. A. Freeman. 1991. Peroxynitrite oxidation of sulfhydryls, the cytotoxic potential of superoxide and nitric oxide. J. Biol. Chem 266, 4244-4250.

19. Roterta, R., P. Nicoletta, P. Anna, P. Ananth, Y. Min, and R. E. Catherine. 1999. Antioxidant Activity Applying an Improved ABTS Radical Cation Decolorization Assay. Free Radic. Biol. Med 26, 1231-1237.

20. Seong, J. K. 2007. Lignan Glycosides of Vaccinium oldhami Miquel, 296, Korean. J. Pharmacogn, Seoul

21. Slominiski, A., G. Moellmann, and E. Kuklinska. 1988. Positive regulation of melanin pigmentation by two key substrate of the melanogenic pathway, L-tyrosinase and L-dopa. J. Cell Sci. 89, 287-296.

22. Swain, T., W. E. Hillis, and M. Ortega. 1959. Phenolic constituents of Ptunus domestica I. Quantitative analysis of phenolic constituents. Sci. of Food Agric. 10, 83-88.

23. Yagi, A, T. Kanbara, and N. Morinobu. 1987. Inhibition of mushroom-tyrosinase by aloe extract. Planta Medica. 53, 517-519. 


\section{초록 : 정금나무 Vaccinium oldham) 열매의 항산화 효과}

채정우 $\cdot$ 공혜진 ${ }^{1} \cdot$ 이미지 ${ }^{1} \cdot$ 박정연 $^{1} \cdot$ 김지향 ${ }^{2} \cdot$ 김영훈 $^{3} \cdot$ 이창언 ${ }^{1} \star$ 김경환

(경기도산림환경연구소, ${ }^{1}$ 대구한의 대학교 화장품약리학과, ${ }^{2}$ (주) 코스메랩 피부과학연구소, ${ }^{3}$ (주) 메디웨이코 리아 피부과학연구소)

천연물들은 현재까지 합성 항산화제들을 대체하기 위하여 많은 연구가 이뤼지고 있다. 본 연구에서는 천연 항 산화제로서 화장품과 바이오산업에 적용하기 위해 정금나무 열매 $70 \%$ 아세톤 추출물의 항산화능을 측정하였다. 정금나무 열매의 항산화능을 확인하기 위하여 폴리페놀의 함량을 측정, 전자공여능, ABTS ${ }^{+}$, nitric oxide, hydrogen peroxide들의 소거 측정을 분석하여 다음과 같은 결과를 얻었다. 폴리페놀의 총 함량은 $55.972 \mathrm{mg} \mathrm{TAE} / \mathrm{g}$ 로 정량 되었다. 전자공여능 실험에서는 농도 의존적으로 DPPH radical 소거능이 증가 하였으며 $500 \mu \mathrm{g} / \mathrm{ml}$ 에서 $98 \%$ 이상의 활성을 나타내어 양성 대조군인 BHA의 활성을 초과하는 것을 알 수 있었다. ABTS ${ }^{+}$에 대한 소거활 성은 $500 \mu \mathrm{gg} / \mathrm{ml}$ 에서 $66.7 \%$ 의 결과로 나타났고, nitric oxide radical 소거능은 $100 \mu \mathrm{gg} / \mathrm{ml}$ 에서 $57 \%$ 의 활성을 나타 내었다. 또한 정금나무 열매 $70 \%$ 아세톤 추출물의 hydrogen peroxide의 소거활성은 $50 \mathrm{\mu g} / \mathrm{ml}$ 에서 정금나무 열 매 추출물은 $70 \%$ 이상의 활성을 나타났으며, BHA 보다 높은 활성을 나타내었다. 천연물의 산업화 가능성에 있어 가장 중요한 것은 재료의 영속적인 수급과 적은 농도를 첨가하여도 높은 효과를 나타내는지의 여부이다. 매년 수확이 가능한 정금나무 열매를 이용한 본 연구의 결과에서 열매의 항산화능 확인 및 화장품 등 바이오산업에 천연항산화제 원료로서의 적용 가능성을 확인할 수 있었다. 